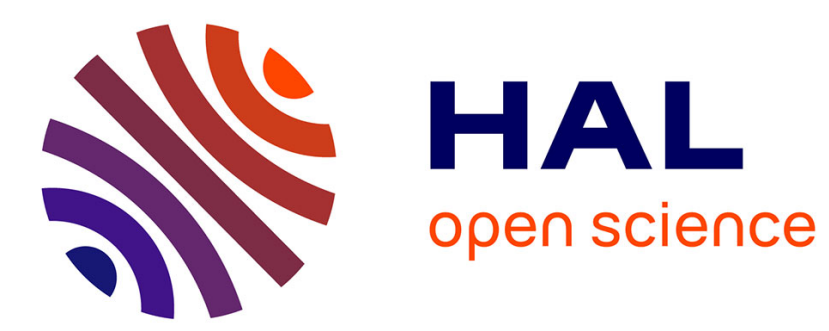

\title{
A new species of Baikuris (Hymenoptera: Formicidae: Sphecomyrminae) in mid-Cretaceous amber from France Vincent Perrichot
}

\section{To cite this version:}

Vincent Perrichot. A new species of Baikuris (Hymenoptera: Formicidae: Sphecomyrminae) in mid-Cretaceous amber from France. Cretaceous Research, 2015, 52 (B), pp.585-590. 10.1016/j.cretres.2014.03.005 . insu-01112039

\section{HAL Id: insu-01112039 https://hal-insu.archives-ouvertes.fr/insu-01112039}

Submitted on 15 Jun 2015

HAL is a multi-disciplinary open access archive for the deposit and dissemination of scientific research documents, whether they are published or not. The documents may come from teaching and research institutions in France or abroad, or from public or private research centers.
L'archive ouverte pluridisciplinaire HAL, est destinée au dépôt et à la diffusion de documents scientifiques de niveau recherche, publiés ou non, émanant des établissements d'enseignement et de recherche français ou étrangers, des laboratoires publics ou privés. 


\title{
A new species of Baikuris (Hymenoptera: Formicidae: Sphecomyrminae) in mid-Cretaceous amber from France
}

\author{
Vincent Perrichot ${ }^{a, b}$ \\ ${ }^{a}$ CNRS UMR 6118 Géosciences \& OSUR, Université Rennes 1, Campus de Beaulieu bât. 15, 263 avenue \\ du Général Leclerc, 35042 Rennes cedex, France; e-mail: vincent.perrichot@univ-rennes1.fr \\ ${ }^{\mathrm{b}}$ University of Kansas Biodiversity Institute, Division of Entomology, Lawrence, KS 66049, USA
}

\begin{abstract}
A new species of the extinct ant genus Baikuris Dlussky, 1987 (Formicidae: Sphecomyrminae) is described and figured from a male preserved in a piece of $<100 \mathrm{Myr}$ amber from Charentes, in southwestern France. Baikuris maximus sp. nov., is distinguished from other species notably by its larger size, its forewing with vein $2 \mathrm{M}+\mathrm{Cu}$ absent and vein $3 \mathrm{Cu}$ tubular, and the presence of a subpetiolar process. The diagnosis of the genus is emended, and its distribution during the Cretaceous is briefly discussed.
\end{abstract}

Keywords: Insecta; ant; Sphecomyrmini; amber; Albian-Cenomanian; France

\section{Introduction}

Sphecomyrminae were among the first ants to colonize the Earth, and they existed for at least 22 million years in the Cretaceous, from the latest Albian (100 Ma) to the middle Campanian (78 Ma). Since the first description of a sphecomyrmine in the late 60's (Wilson et al., 1967), the group's diversity has reached 18 species in 9 genera, yet it remains one of the most puzzling of all ant subfamilies. The female castes exhibit a variety of 'standard' (e.g., Sphecomyrma Wilson and Brown, 1967, Sphecomyrmodes Engel and Grimaldi, 2005) and highly specialized (e.g., Haidomyrmex Dlussky, 1996, Zigrasimecia Barden and Grimaldi, 2013) head morphologies, and of the ant synapomorphies, sphecomyrmines lack only the elongated scapes. The only tentative placement of the group within a phylogenetic framework, conducted by Grimaldi et al. (1997), is now largely outdated given the substantial recomposition of the ant subfamilies (Bolton, 2003, Rabeling et al., 2008) and the progress in the understanding of their relationships based on morphological and molecular studies (Brady et al., 2006, Moreau et al., 2006, Keller, 2011, Moreau and Bell, 2013).

Sphecomyrmines had a wide distribution although apparently restricted to Laurasia. They are known exclusively in amber, however, so this evident bias of preservation likeky gives us a wrong picture of their actual diversity and distribution through the Cretaceous. Fossils of Sphecomyrminae have been unearthed from mid-Cretaceous ambers of France and Myanmar, and Late Cretaceous ambers of the U.S. Atlantic Coastal Plain, Siberia, and Canada (see LaPolla et al., 2013: tab. 1, with additions of Barden and Grimaldi, 2013, McKellar et al., 2013, Krynicki, 2013, Perrichot, 2014). Among these, the genus Baikuris is known exclusively from males and was first described from late Cretaceous (Campanian?) Taimyr amber of Baikura by Dlussky (1987), with the two species B. mandibularis Dlussky, 1987 and B. mirabilis Dlussky, 1987. A 

New Jersey amber (Grimaldi et al., 1997).

A fourth species of Baikuris is described herein, based on a male from latest Albian earliest Cenomanian (approximately $100 \mathrm{Myr}$ ) amber of southwestern France, known as Charentese amber.

\section{Material and methods}

The material comprises a single specimen, a nearly complete male missing only the right antenna with a small frontal area and apical part of the right foreleg, and preserved in a cylindrical piece of dark amber which was collected in 2000 by the author from the Font-de-Benon quarry near Archingeay, in the Charentes region (Fig. 1A). The amber comes from the lowermost of two amber-bearing strata present in this quarry (Fig. 1B), i.e. the latest Albian - earliest Cenomanian level A1sl-A sensu Perrichot et al. (2010), also named A1s11 sensu Néraudeau et al. (2002). It is the same outcrop and geological stratum that yielded the holotypes of Gerontoformica cretacica and Haidomyrmodes mammuthus, two other fossil ants described earlier by Nel et al. (2004) and Perrichot et al. (2008), respectively. Details on the geology, paleobiota, and paleoenvironment of this fossil deposit were provided by Perrichot et al. (2010).

The amber piece was so turbid that the ant and three other fossil inclusions (two Diptera and one Hymenoptera: Platygastridae) were hardly discernable. The piece was cut in three parts and a razor blade was used to remove the maximum of amber surrounding the fossils for an optimal observation of each inclusion. The ant could not be separated from a crane fly (Diptera: Limoniidae, assignable to Antodicranomyia azari Perrichot, Nel, and Krzeminski, 2007) that contacted its left antenna. The head was still poorly visible so black ink was injected through the missing part of frons for enabling better visibility. Then a small drop of epoxy was placed to close the hole, and the amber fragment was placed between cover slips and embedded in Canada balsam following established techniques (Azar et al., 2003). The material is deposited in the Geological Department and Museum of the University Rennes 1, France.

The specimen was examined under incident and transmitted light using a Leica MZ APO stereomicroscope, and imaged with the aid of a Canon 5D Mark II camera attached to it. Stacks of photographs taken at different depths of field were merged using HeliconFocus software (HeliconSoft Ltd.). All photographs will be made freely available on AntWeb (www.antweb.org) upon publication of this article. Line drawings were made with a camera lucida and digitally processed using Illustrator CS4 software. Measurements were made using the ocular graticule of the stereomicroscope. The wing vein nomenclature follows Perfilieva (2011).

\section{Systematic palaeontology}

Family: Formicidae Latreille, 1802

Subfamily: Sphecomyrminae Wilson \& Brown, 1967

Tribe Sphecomyrmini Wilson \& Brown, 1967

Genus Baikuris Dlussky, 1987

Type species. Baikuris mandibularis Dlussky, 1987: 134, fig. 2. See also Perfilieva, 2011: figs. 3a-c, pl. 6.6-6.8.

Diagnosis (from Dlussky, 1987; Grimaldi et al., 1997, with emended characters in italics). Males having large eyes oval to reniform; mandibles narrow, with margins virtually parallel, 
masticatory margin without teeth; base of outer surface with oval area and ridge (opening of mandibular gland?); maxillary palps long, 6-segmented; labial palps 4-segmented (visible in $B$. casei); scutum with distinct parapsidal grooves; forewing venation complete (class I in Perfilieva's (2011) terminology), with cell 1+2r six-angled, cross-vein 1r-rs absent or tubular for a short distance, vein $2 M+C u$ short or absent, distal portion of $\mathrm{Cu}(3 \mathrm{Cu})$ spectral and not reaching wing margin, or tubular and almost reaching wing margin; mid and hind legs with trochantellus; fore tibia with one apical spur (two spurs incorrectly mentioned in Grimaldi et al., 1997), mid and hind tibiae with two apical spurs; tarsal claws with small preapical tooth; petiole nodiform, low and elongate; a more or less distinct constriction between first and second gastral segments; genitalia small and retracted into gastral segments; cerci well developed.

Baikuris maximus Perrichot, sp. nov.

Figs. 2-3

Diagnosis. Differs from other Baikuris species by its larger size (11.5 $\mathrm{mm}$ for the body length, as opposed to a maximum of $8 \mathrm{~mm}$ for other species), the presence of a subpetiolar process, and the forewing with crossvein 1r-rs complete although largely spectral, its tubular portion not exceeding $0.33 \times$ total length, with vein $3 \mathrm{Cu}$ tubular, almost touching wing margin, with $2 \mathrm{M}+\mathrm{Cu}$ absent. These and other characteristics of the different species are summarized in table 1 . Derivation of name. The specific epithet is taken directly from the Latin adjective meaning "biggest", and refers to the large size of the specimen.

Holotype. IGR.ARC-112.1, male; deposited in the Geological Institute and Museum of the University Rennes 1, France.

Type locality and horizon. Font-de-Benon quarry, ca. $1 \mathrm{~km}$ east of Archingeay, CharenteMaritime, France; Cretaceous, Latest Albian - Earliest Cenomanian (ca. $100 \mathrm{Ma}$ ), lithological level A1sl-A.

Description. Male large, body length $11.5 \mathrm{~mm}$. Head length $1.80 \mathrm{~mm}$ (excluding mandibles), width $1.05 \mathrm{~mm}$ (excluding eyes). Compound eyes large, maximal length $1.05 \mathrm{~mm}$, reniform, strongly convex, in full-face view situated beyond the outlines of the sides of head. Ocelli large, prominent. Frons and right antenna not preserved. Antenna long and filiform, total length 10.4 $\mathrm{mm}$; scape short, about $0.4 \times$ length of flagellomere I; pedicel very short, as long as broad, $0.45 \times$ length of scape; flagellomere I (fI) longest antennomere, fIII slightly longer than fII, following segments increasingly shorter except apical flagellomere only slightly longer than preceding segment, narrowly tapered at apex; length of antennomeres (in $\mathrm{mm}$ ): scape 0.40 , pedicel 0.18 , flagellomeres fI 1.30, fII 1.03, fIII 1.05, fIV 1.00, fV 0.95, fVI 0.90, fVII 0.82, fVIII 0.75, fIX 0.70 , fX 0.64 , fXI 0.66. Clypeus and mouthparts largely obscured by preservation; anterior clypeal margin distinctly convex; mandibles small, with sides parallel, apparently with a small preapical tooth; maxillary palps long, five segments visible; labial palps not visible. Occipital carina present.

Mesosoma. Propleuron somewhat elongate, forming a neck dorsally. Scutellum with deep parapsidal grooves widely separated posteriorly, distinctly diverging anteriorly. Legs long and slender; trochantellus visible on hind leg only, possibly present on mid leg but obscured; fore tibia apically with one pectinate spur (strigil); mid tibia with two simple spurs subequal in length; hind tibia with one short, simple spur, and one long, pectinate spur; tarsomere I of all legs with longitudinal row of short erect setae on inner surface; inner surface of tarsomeres I-IV apically with pair of spinelike setae (visible on left mid and hind legs); pretarsal claws with a distinct preapical tooth. Forewing length $6.8 \mathrm{~mm}$; distal portion of $\mathrm{M}(4 \mathrm{M})$ and $\mathrm{Cu}(3 \mathrm{Cu})$ tubular, 

pterostigma; crossvein cu-a aligned with $1 \mathrm{M}(2 \mathrm{M}+\mathrm{Cu}$ absent $)$. Hind wings largely hidden underneath forewings, only median anterior third visible; anterior margin with four basal and seven distal hamuli; R, 1R1, 1Rs, 2Rs, rs-m, 1M, and 2M apparently all tubular.

Metasoma. Petiole with short anterior peduncle and distinct node, its length $(1.20 \mathrm{~mm})$ twice greatest height; an acute, triangular subpetiolar process situated on ventral surface just posterior to peduncle; attachment of petiole on propodeum low, not particularly thick. First gastral segment (abdominal segment III) bell-shaped, approximately $0.9 \times$ length of petiole; a distinct constriction between gastral segments I and II and a slight constriction between gastral segments III and IV; apical portion of gaster not visible, retracted inside preceding segment (abdominal segment VI).

Remarks. The new fossil exhibits the main synapomorphies of the genus Baikuris, which are the eyes reniform, the mandibles narrow and rectangular, without conspicuous tooth, the scape/pedicel ratio, the presence of deep parapsidal grooves, the forewing with cell $1+2 \mathrm{r}$ partly divided by a rudimentary cross-vein 1r-rs, and the petiole nodiform, low and elongate.

\section{Discussion}

The new specimen is the oldest known record of the genus Baikuris, which is now known by four species ranging from the Albian-Cenomanian boundary to the Campanian (100 Ma to 80 Ma approximately). As for all sphecomyrmine ants, the genus is known exclusively from amber fossils and its apparent distribution is restricted to the mid and high latitudes of the Northern Hemisphere, more precisely to continents that formed Laurasia during the Cretaceous (Fig. 4). It is still difficult to associate Baikuris with any of the known female castes of Sphecomyrminae: in Charentese amber, female ants belong to the genera Sphecomyrmodes and Haidomyrmodes Perrichot et al., 2008 (also Gerontoformica Nel and Perrault, 2004, which was described as uncertain in subfamily but may belong to Sphecomyrminae as well); in New Jersey amber, females are assignable to Sphecomyrma and another male morphotype was tentatively assigned to Sphecomyrma already; and no female caste is known from Baikura amber (Fig. 4). So there is no recurrent association of Baikuris with another genus known from females which could indicate congeneric castes.

\section{Conclusion}

The middle of the Cretaceous has been a key period in the early evolution of ants, yet our understanding of the diversity, paleoecology, and paleobiogeography of ant lineages that existed at the time is scant. Fossil discoveries have greatly increased in the past two decades, which progressively fill the gap, and the new species described here adds to the knowledge of the most basal of these lineages, the Sphecomyrminae. The family is most diversified in the earliest Cenomanian of Myanmar, but specimens found in amber from the Albian-Cenomanian of France, Turonian of New Jersey, Santonian to Campanian of Siberia, and Campanian of Canada, demonstrate a broad distribution across Laurasia.

\section{Acknowledgements}

I am grateful to Dany Azar for his help with the delicate preparation of the specimen; to the family Marchand for facilitating access to their quarry; and to Didier Néraudeau and Blaise Videt 
for their assistance in collecting of the amber during summer 2000. Comments from two anonymous reviewers improved an earlier version of this paper. This work is a contribution of the Division of Entomology, University of Kansas Biodiversity Institute.

\section{References}

Azar, D., Perrichot, V., Néraudeau, D., Nel, A., 2003. New psychodids from the Cretaceous ambers of Lebanon and France, with a discussion of Eophlebotomus connectens Cockerell, 1920 (Diptera, Psychodidae). Annals of the Entomological Society of America 96, 117126

Barden, P., Grimaldi, D.A., 2013. A new genus of highly specialized ants in Cretaceous Burmese amber (Hymenoptera: Formicidae). Zootaxa 3681, 405-412.

Blakey, R.C., 2011. Library of Paleogeography, Colorado Plateau Geosystems, Inc. Mollewide Globes, Late Cretaceous (90 mya). http://cpgeosystems.com/90moll.jpg [accessed December 2013].

Bolton, B., 2003. Synopsis and classification of Formicidae. Memoirs of the American Entomological Institute 71, 1-370.

Brady, S.G., Schultz, T.R., Fisher, B.L., Ward, P.S., 2006. Evaluating alternative hypotheses for the early evolution and diversification of ants. Proceedings of the National Academy of Sciences of the USA 103, 18172-18177.

Dlussky, G.M., 1987. New Formicoidea (Hymenoptera) of the Upper Cretaceous. Paleontological Journal 20, 146-150.

Grimaldi, D.A., Agosti, D., Carpenter, J.M., 1997. New and rediscovered primitive ants (Hymenoptera: Formicidae) in Cretaceous amber from New Jersey, and their phylogenetics relationships. Am. Mus. Novit. 3208: 1-43.

Keller, R.A., 2011. A phylogenetic analysis of ant morphology (Hymenoptera: Formicidae) with special reference to the poneromorph subfamilies. Bulletin of the American Museum of Natural History 355, 1-90.

Krynicki, V.E., 2013. Primitive ants (Hymenoptera: Sphecomyrminae) in the Campanian (Late Cretaceous) of North Carolina (USA). Life: The Excitement of Biology 1, 156-165.

LaPolla, J.S., Dlussky, G.M. \& Perrichot, V., 2013. Ants and the fossil record. Annual Review of Entomology 58, 609-630.

McKellar, R.C., Glasier, J., Engel, M.S., 2013. A new trap-jawed ant (Hymenoptera: Formicidae: Haidomyrmecini) from Canadian Late Cretaceous amber. The Canadian Entomologist 145, 454-465.

Moreau, C.S., Bell, C.D., 2013. Testing the museum versus cradle tropical biological diversity hypothesis: phylogeny, diversification, and ancestral biogeographic range evolution of the ants. Evolution 67, 2240-2257.

Moreau, C.S., Bell, C.D., Vila, R., Archibald, S.B., Pierce, N.E., 2006. Phylogeny of the ants: diversification in the age of angiosperms. Science 312, 101-104.

Nel, A., Perrault, G., Perrichot, V., Néraudeau, D., 2004. The oldest ant in the Lower Cretaceous amber of Charente-Maritime (SW France) (Insecta: Hymenoptera: Formicidae). Geologica Acta 2, 23-29.

Néraudeau, D., Perrichot, V., Dejax, J., Masure, E., Nel, A., Philippe, M., Moreau, P., Guillocheau, F., Guyot, T., 2002. Un nouveau gisement à ambre insectifère et à végétaux 
(Albien terminal probable): Archingeay (Charente-Maritime, France). Geobios 35, 233240.

Perfilieva, K.S., 2011. New data on the wing morphology of the Cretaceous Sphecomyrminae ants (Hymenoptera: Formicidae). Paleontological Journal 45, 275-283.

Perrichot, V., 2014. A new species of the Cretaceous ant Zigrasimecia based on the worker caste reveals placement of the genus in the Sphecomyrminae (Hymenoptera: Formicidae). Myrmecological News 19, 165-169.

Perrichot, V., Nel, A., Néraudeau, D., Lacau, S., Guyot, T., 2008. New fossil ants in French Cretaceous amber (Hymenoptera: Formicidae). Naturwissenschaften 95, 91-97.

Perrichot, V., Néraudeau, D., Tafforeau, P., 2010. Charentese amber. In: Penney D. (Ed.), Biodiversity of fossils in amber from the major world deposits. Siri Scientific Press, Manchester, pp. 192-207.

Rabeling, C., Brown, J.M., Verhaagh, M., 2008. Newly discovered sister lineage sheds light on early ant evolution. Proceedings of the National Academy of Sciences of the USA 105, 14913-14917.

Wilson, E.O., Carpenter, F.M., Brown, W.L.Jr., 1967. The first Mesozoic ants, with the description of a new subfamily. Psyche 74, 1-19. 
Table 1. Comparison of Baikuris species.

\begin{tabular}{lllll}
\hline & B. mandibularis & B. mirabilis & B. casei & B. maximus sp. nov. \\
\hline body length & $4-5 \mathrm{~mm}$ & $8 \mathrm{~mm}$ & $7.5 \mathrm{~mm}$ & $11.5 \mathrm{~mm}$ \\
eyes & reniform & reniform & oval & reniform \\
$\begin{array}{l}\text { antennomeres I-IV } \\
\text { ratio }\end{array}$ & $1 / 0.5 / 2.9 / 2.0$ & $?$ & $1 / 0.45 / 2 / ?$ & $1 / 0.46 / 2.8 / 2.66$ \\
forewing r-rs & incomplete, tubular for & nearly complete, & absent & nearly complete, \\
& $\begin{array}{l}\text { 1/2 distance to } \\
\text { pterostigma }\end{array}$ & spectral & & $\begin{array}{l}\text { to pular for } 1 / 3 \text { distance } \\
\text { spectral }\end{array}$ \\
& & & & absent \\
forewing 2M+Cu & short & short & short & tubular, almost \\
forewing 3Cu & spectral & spectral & absent & reaching wing margin \\
subpetiolar process & absent & & absent & present \\
$\begin{array}{l}\text { gastral constriction } \\
\text { between segments I-II }\end{array}$ & slight & absent & slight & deep \\
\hline
\end{tabular}




\section{Figure captions}

Fig. 1. Geographical and geological setting of the Cretaceous ant-bearing amber deposits from the Charentes region. A - Location of the sites with indication of all known fossil ant taxa, including Baikuris maximus sp. nov. B - Regional stratigraphic section with indication of the two amber levels with fossil ants (numbers of sites correlate with Fig. 1A).

Fig. 2. Baikuris maximus sp. nov., holotype IGR.ARC-112.1, from Charentese amber. A. Dorsolateral habitus. B. Head in full-face view. C. Left meso- and metathoracic legs. D. Forewings. E. Metasoma in profile view.

Fig. 3. Line drawings of Baikuris maximus sp. nov. A. Lateral habitus; the arrows indicate the subpetiolar process and the gastral constriction. B. Head in full face view. C. Left forewing, with indication of veins mentioned in the description; tubular veins in black, spectral vein in grey.

Fig. 4. Palaeogeographical distribution of the genus Baikuris, with other sphecomyrmine genera and their castes (m: male; w: worker; q: gyne) known from the same amber deposits; early Late Cretaceous map ( $90 \mathrm{Ma})$ modified from Blakey (2011). 

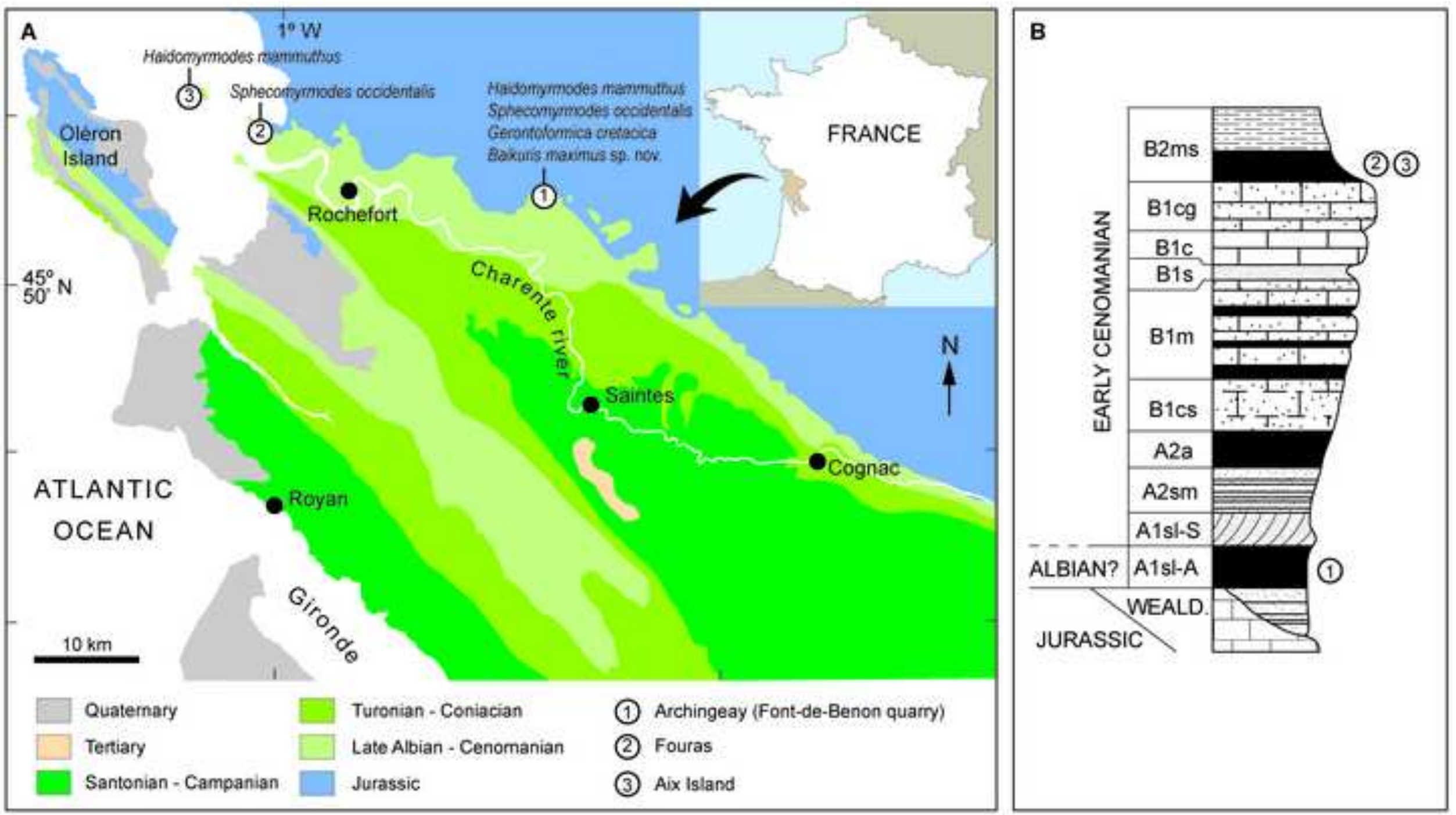
Click here to download high resolution image
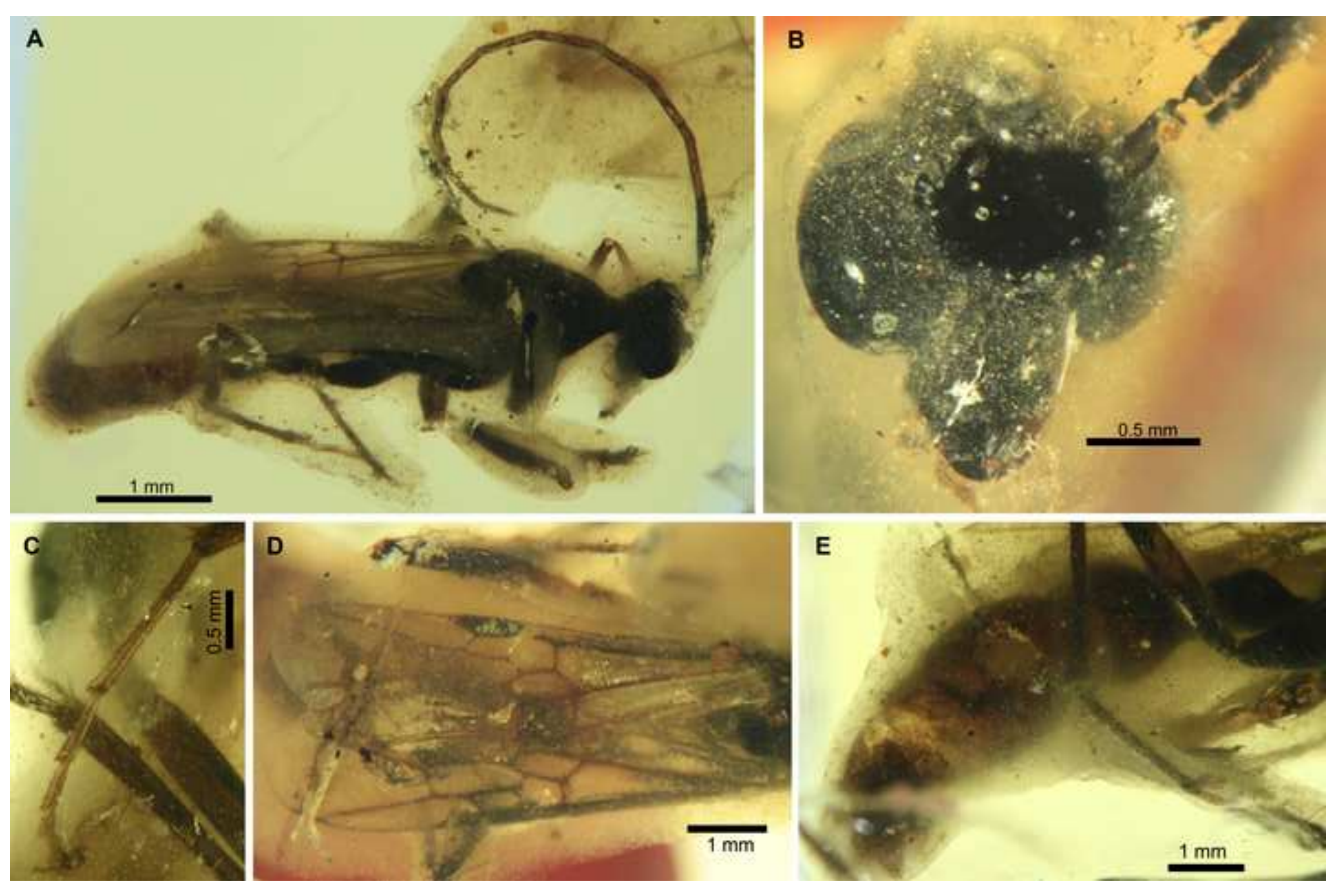

\section{Click here to download high resolution image}




\section{Figure 3}

Click here to download high resolution image

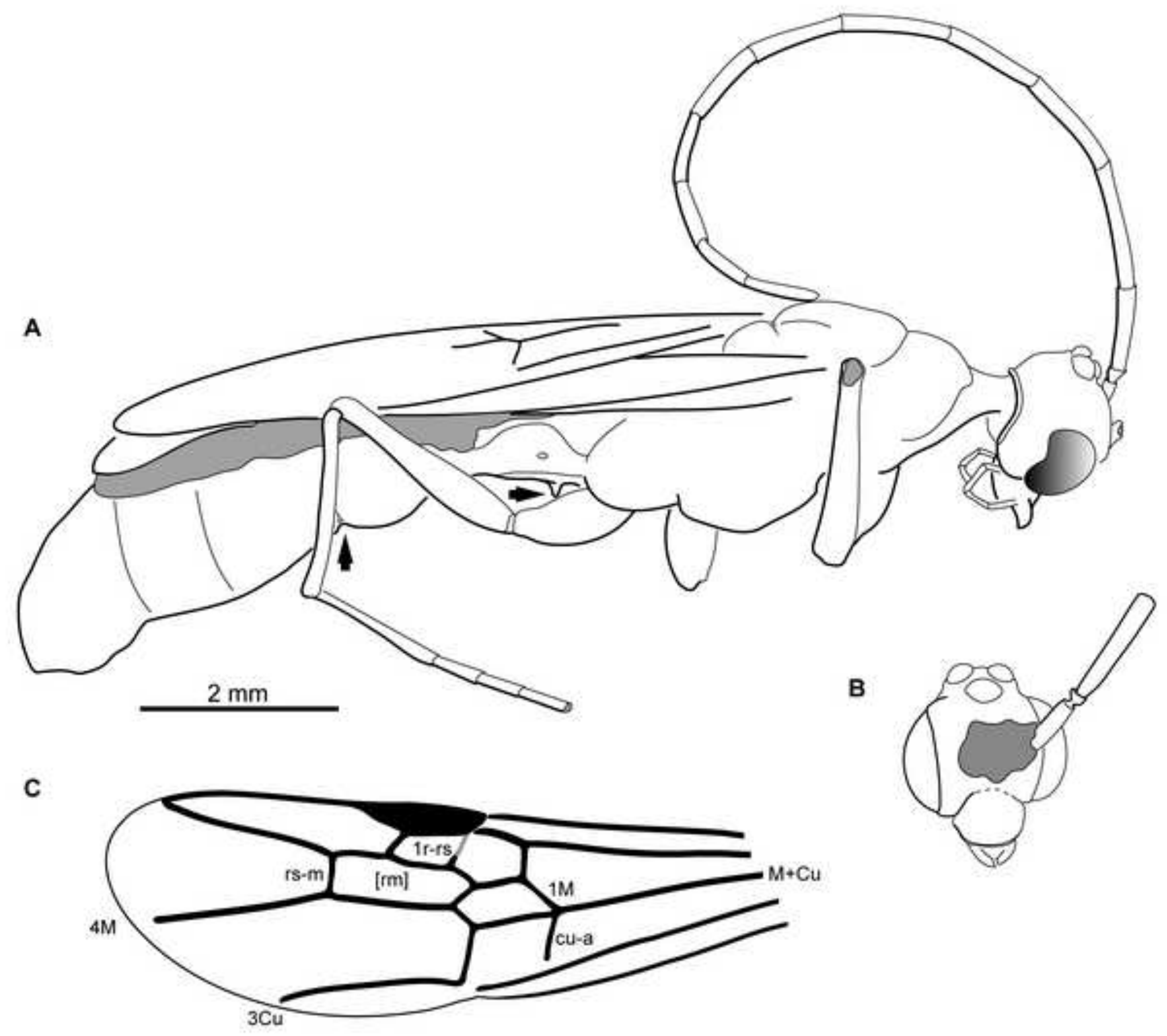




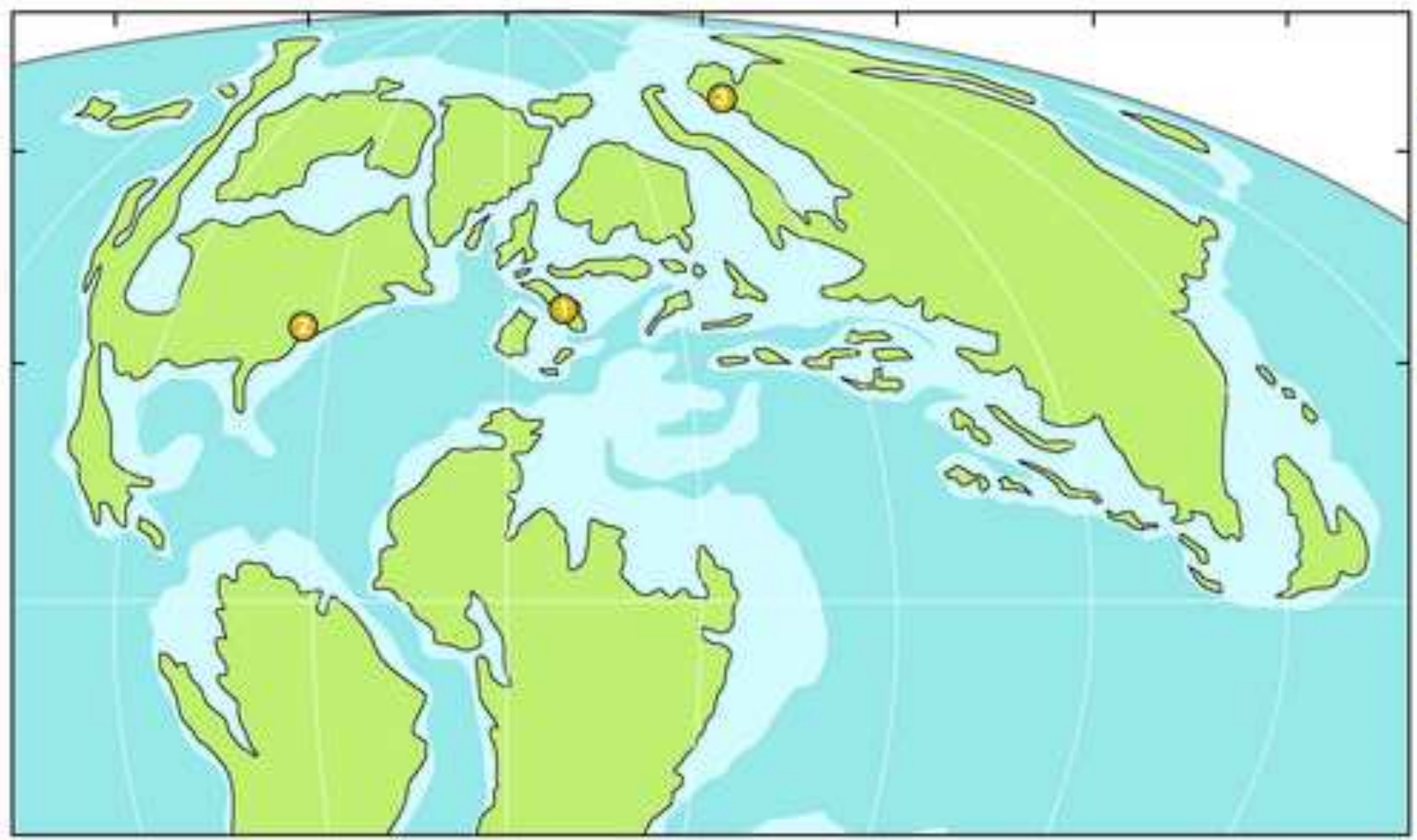

\section{Charentese amber (100 Ma):}

Baikuris (m). Haidomyrmodes (q, w)

Sphecomyrmodes (w). Gerontoformica (w)

(1) New Jersey amber (92 Ma):

Baikuris (m), Haidomymodes (q, w), Sphecomyrma ( $w, m$ ?)

Taimyr (Baikura) amber ( $80 \mathrm{Ma})$ : Baikuris (m) 